\title{
Identification of diabetic neuropathic patients at risk of foot ulceration through finite element models and cluster analysis
}

\author{
Annamaria Guiotto ${ }^{1 *}$, Zimi Sawacha ${ }^{1}$, Alessandra Scarton ${ }^{1}$, Gabriella Guarneri ${ }^{2}$, Angelo Avogaro ${ }^{2}$, Claudio Cobelli ${ }^{1}$ \\ From 4th Congress of the International Foot and Ankle Biomechanics (i-FAB) Community \\ Busan, Korea. 8-11 April 2014
}

\section{Background}

Diabetic foot is an invalidating complication of diabetes mellitus that can lead to foot ulceration and amputations. While experimental analyses are limited solely to measurements of interfacial variables, three-dimensional (3D) patient specific finite element models (FEMs) of the foot can provide both the interfacial pressures and insight into internal stresses and strains tolerated by the plantar tissue [1]. FEMs allows quantifying the loads developed in the different anatomical structures of the foot and to understand how these affect foot tissue [2]. The aim of this study was to identify the neuropathic subjects at risk of ulceration with a cluster analysis classification of simulated plantar pressures and internal stresses. Simulations were ran with gait analysis data acquired 5 years prior to ulcerations.

\section{Methods}

Foot biomechanical analysis was carried out as in [3] on 16 diabetic neuropathic subjects by measn of a 6 cameras

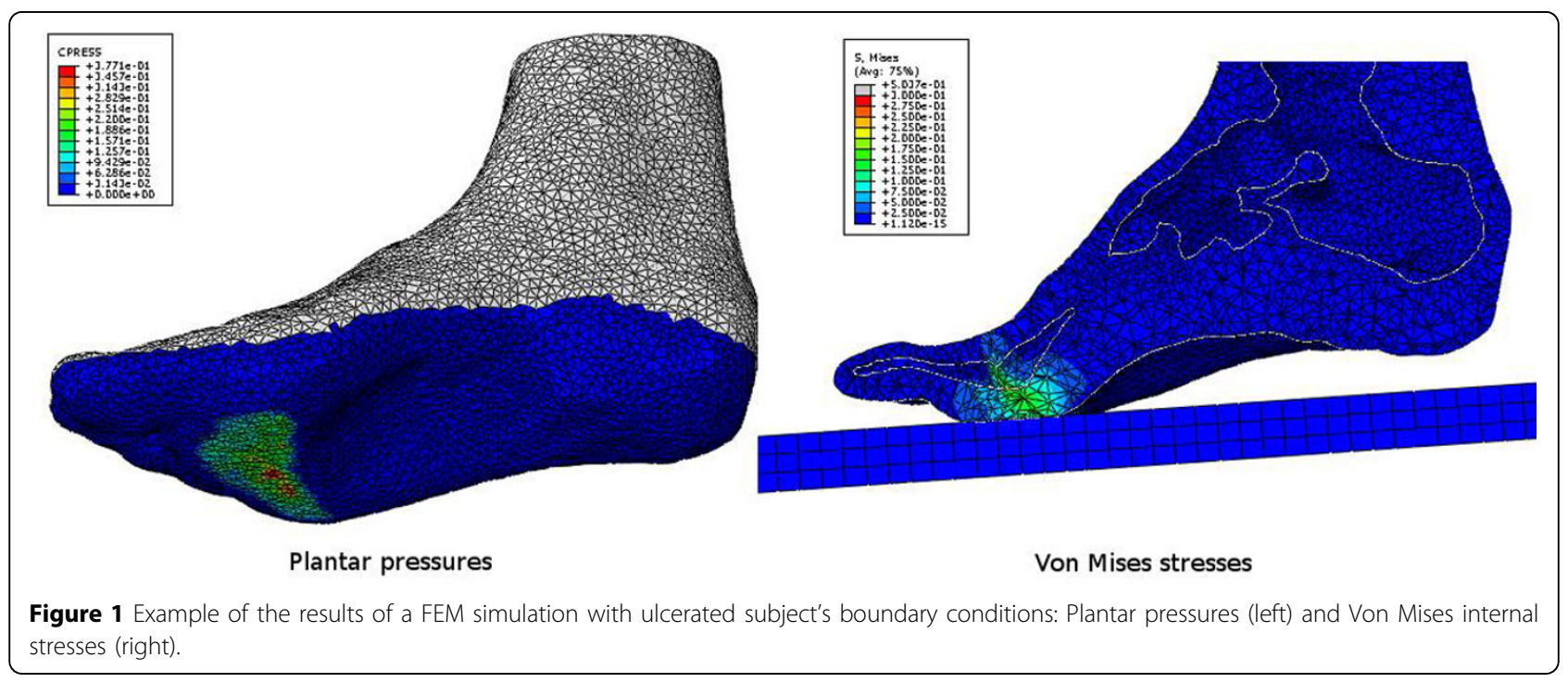

\footnotetext{
* Correspondence: guiotto@dei.unipd.it

'Department of Information Engineering, University of Padova, Padova,

35131, Italy

Full list of author information is available at the end of the article
} 
Table 1 Results of the hierarchical cluster analysis: 3 clusters. Values are normalized over the subject's weight. $\mathrm{PP}=$ plantar pressure.

\begin{tabular}{|c|c|c|c|c|c|c|c|}
\hline Cluster & $\mathrm{N}^{\circ}$ subjects ulcer/no ulcer & Push-off & & & Mid-stanc & & \\
\hline & & Peak PP & Mean PP & Von Mises & Peak PP & Mean PP & Von Mises \\
\hline \multirow[t]{2}{*}{1} & $0 / 3$ & 0.423 & 0.108 & 0.000381 & 0.323 & 0.080 & 0.000251 \\
\hline & & 0.052 & 0.023 & 0.000174 & 0.020 & 0.010 & 0.000044 \\
\hline \multirow[t]{2}{*}{2} & $1 / 4$ & 0.371 & 0.097 & 0.000348 & 0.275 & 0.060 & 0.000245 \\
\hline & & 0.041 & 0.019 & 0.000050 & 0.017 & 0.007 & 0.000024 \\
\hline \multirow[t]{2}{*}{3} & $5 / 3$ & 0.390 & 0.104 & 0.000378 & 0.277 & 0.062 & 0.000228 \\
\hline & & 0.035 & 0.007 & 0.000042 & 0.028 & 0.004 & 0.000021 \\
\hline
\end{tabular}

motion capture system (BTS, Padova), integrated and synchronized with 2 force plates (Bertec, USA), 2 plantar pressures systems (Imagortesi, Piacenza). For each patient the 3D kinematics, ground reaction forces and plantar pressures were calculated. Six of these subjects developed ulcers under metatarsals heads within 5 years after the acquisitions (ulcerated subjects (US)- age 62.3 \pm 4.1 years, BMI $26.3 \pm 2.0 \mathrm{~kg} / \mathrm{m}^{2}$ ) while the other ten did not (non US - age $63.2 \pm 6.4$ years, BMI $24.3 \pm 2.9 \mathrm{~kg} / \mathrm{m}^{2}$ ).

In order to obtain the internal stresses (Von Mises and principal stresses) and the simulated plantar pressures (Figure 1), a recently developed 3D FEM [4] was adopted and the simulations were run adopting the experimental kinematic and kinetics as boundary conditions as in [4]. The midstance and the push-off phases of gait were considered as they are the instants when critical loads occur in the forefoot of the diabetic subjects.

$\mathrm{K}$-means and hierarchical cluster analysis were performed as in [5] with simulated plantar pressures and/or internal stresses as input.

\section{Results}

The hierarchical method (Ward's linkage) which led to the definition of three clusters (Table 1) gave the best result: 5 US were included in one cluster with only 3 non US.

\section{Conclusions}

A longer follow up is needed in order to verify whether the neuropathic subjects in cluster 2 and 3 will develop ulcers. A larger dataset is needed to further validate this methodology. Besides these limitations, results showed that combined FEMS and cluster analysis allowed to infer useful informations on the risk of ulceration even five years prior to the wound evolution.

\section{Authors' details}

${ }^{1}$ Department of Information Engineering, University of Padova, Padova, 35131, Italy. ${ }^{2}$ Department of Clinical Medicine and Metabolic Disease, University Polyclinic, Padova, 35128, Italy.

Published: 8 April 2014

\section{References}

1. Yarnitzky G, Yizhar Z, Gefen A: Real-time subject-specific monitoring of internal deformations and stresses in the soft tissues of the foot: a new approach in gait analysis. Journal of Biomechanics 2006, 39:2673-2689.

2. Cavanagh P, Erdemir A, Petre M, Owings T, Botek G, Chokhandre S, Bafna R: Biomechanical factors in diabetic foot disease. Journal of Foot and Ankle Research 2008, 1:K4.

3. Sawacha Z, Guarneri G, Cristoferi G, Guiotto A, Avogaro A, Cobelli C: Integrated kinematics-kinetics-plantar pressure data analysis: A useful tool for characterizing diabetic foot biomechanics. Gait \& Posture 2012, 36:20-26.

4. Guiotto A, Sawacha Z, Scarton A, Guarneri G, Avogaro A, Cobelli C: 3D finite element model of the diabetic neuropathic foot: a gait analysis driven approach. Proceedings ISB Natal, Brasil; 2013.

5. Sawacha Z, Laudani L, Macaluso A, Vannozzi G: Identifying The Association Between Physical Activity Levels And Physiological Factors Underlying mobility: a descriptive data mining approach. Proceedings of IDAMAP Pavia, Italy; 2012.

\section{doi:10.1186/1757-1146-7-S1-A27}

Cite this article as: Guiotto et al:: Identification of diabetic neuropathic patients at risk of foot ulceration through finite element models and cluster analysis. Journal of Foot and Ankle Research 2014 7(Suppl 1):A27.

\section{Submit your next manuscript to BioMed Central} and take full advantage of:

- Convenient online submission

- Thorough peer review

- No space constraints or color figure charges

- Immediate publication on acceptance

- Inclusion in PubMed, CAS, Scopus and Google Scholar

- Research which is freely available for redistribution 